Thomas Lucien Blair (Boston): Intensive Hausa language training and study of urbanization in Northern Nigeria (England and Nigeria).

George Edward Brooks, Jr. (Boston): Research and writing of doctoral dissertation on American legitimate commerce with West Africa, 1789-1914, at Boston University.

Marian Elizabeth Doro: Research on Kenya's Legislative Council I944-6I (Kenya and England).

Nicholas England (Baylor): Completion of doctoral dissertation on Bushman cultures of South-West Africa, Bechuanaland, and the Union of South Africa, at Harvard University. William Jay Foltz (Yale): Research and writing of doctoral dissertation on the Mali Federation (West Africa and Yale).

Elaine Catherine Hagopian (Boston): Research and writing of doctoral dissertation on Berber history and the ethnology of selected Moroccan Berber tribes (Morocco and Boston).

Richard Neal Henderson (Berkeley, California): Research and writing of doctoral dissertation on social structure and change in Onitsha, Nigeria (Nigeria, England, and Berkeley).

Charles Henri la Munière (Harvard): Research and writing of doctoral dissertation on his survey of the fishing industry of the Kafue River (Northern Rhodesia and Harvard).

Michael Frank Lofchie (Berkeley, California): Swahili language training, African area studies, and research on conflict and opposition in the Tanganyika African National Union (Duquesne, Berkeley, and Tanganyika).

Gerard Lucas (Stanford): Research on French educational policy and practice in relation to the individual and national aspirations of the Congolese (England, France, and Congo). Norman William Mosher (Maryland): Research and writing of doctoral dissertation on methods of financing capital formation in Ghana (Washington, D.C., New York, and Boston).

Sayre Perry Schatz (Hofstra College): Study of the effectiveness of government measures to stimulate Nigerian private investment (Nigeria).

Leon Siroto (Columbia): Writing of doctoral dissertation on the role of masks in the culture of the BaKwele people in the Republic of the Congo, at Columbia University.

Audrey Yolonda Smedley (Manchester): Research and writing of doctoral dissertation on the effects of social and economic changes on a pagan community in Nigeria (Nigeria and England).

The following have been awarded fellowships for African studies at American Universities:

Jonathan Shedd Barker: Completion of the requirements for the Ph.D. degree in political science, at the University of California, Berkeley.

Douglas Christian Kelley: Political science and intensive Ibo language training, at Harvard University.

Marian Ellen McReynolds: Government, at Boston University.

Linda Sue Mirin: Government and economics, at Radcliffe College and Boston University.

\title{
Conference on African History and Archaeology
}

A THIRD Conference on African History and Archaeology was held at the School of Oriental and African Studies, University of London, from 3 to 7 July 196r. Like its predecessors in 1953 and 1957, the Conference aimed at uniting workers from a number of countries and disciplines in a series of planned discussions surveying recent developments in the investigation of the post-Stone Age past of Africa, and pinpointing some major problems, particularly those of an interdisciplinary nature. There was yet a further increase in the size of the Conference; though a number of those invited were unable to accept, the overall attendance at the Conference amounted to some 170 persons, while a further 24 
submitted papers in absentia. As well as historians and archaeologists, the Conference embraced, inter alia, anthropologists (both social and physical), botanists, geographers, lawyers, linguists, and political scientists. About half the members came from outside the United Kingdom: some fifteen African countries were represented, Nigeria with $2 \mathrm{I}$ and Ghana with ro members providing the largest contingents, and there were also members from the U.S.A. (eight), France (seven), Belgium (five), India (two), Portugal, and Germany.

Some II papers had been submitted and circulated in advance, and these provided the basis for the discussions at the Conference. The four morning sessions were devoted to general surveys of progress made or being made since the last conference. Dr. R. A. Oliver, the Conference Chairman, presided at the two sessions devoted to history and archaeology before the nineteenth century. The range and variety of the work discussed here was extremely wide, and the discussions were valuable in providing an overall frame within which it could be seen in perspective. The sessions allocated to the nineteenth century (Chairman: Professor G. W. Irwin) and to the twentieth century (Chairman: Professor Kenneth Ingham) were more orthodox, though still demonstrating the value of interdisciplinary co-operation even for the most recent periods of African history.

The afternoon discussions were devoted to particular themes, those on 4 and ; July being presided over by Dr. J. D. Fage (Secretary of the Conference) and that on 6 July by Dr. A. A. Boahen. On 4 July there was a very profitable discussion on the history of food crops in Africa, in which botanists, led by Professor R. Portères, and archaeologists, led by Dr. J. Desmond Clark, joined with geographers and others in pooling deductions made from very different sorts of evidence. There were two meetings in the afternoon of $s$ July. In the first, there was a most useful discussion on the value of glottochronological techniques in Africa and on Professor M. Guthrie's recent work on the Bantu languages and its implications for early Bantu history. Following this there was a discussion on the value of blood-groups and other genetical characters as evidence of the African past. On 6 July, the existing state of knowledge of trade and trade-routes in pre-colonial Africa was considered.

The Conference ended in the afternoon of 7 July with a business meeting. In a final statement, the Conference expressed the wish that the centre of gravity of African historical studies would shift increasingly to Africa itself, and that to aid their development every effort would be made throughout the continent to preserve archives and archaeological remains and to secure to all scholars freedom of research, teaching, and publication. The Conference also passed specific resolutions calling for the production of a series of guides to archival material relevant to African history and also to the documents in Arabic script available for the history of sub-Saharan Africa; for the initiation of a series of translations making available the major texts of African history to African students; for the co-operative investigation of the history of the region between Lake Chad and the Nile; and for international support to initiate archaeological and historical research in the Somali Republic.

$$
\text { (Communicated by Dr. J. D. Fage) }
$$

\section{Recent Research at the Nigerian Institute of Social and Economic Research, University College, Ibadan}

AN account of the activities of the N.I.S.E.R., University College, Ibadan, is given in its recently published Annual Report for I960-I. These include the following studies:

The social and economic history of the Cameroons, by Mr. E. W. Ardener, for which documentary material from various sources including the German records has been examined and classified; his earlier study of fertility and marriage stability among the Bakweri had been completed and arrangements for publication are being made.

The Igala in Kabba Province, by Mr. J. S. Boston, including the pattern of social 